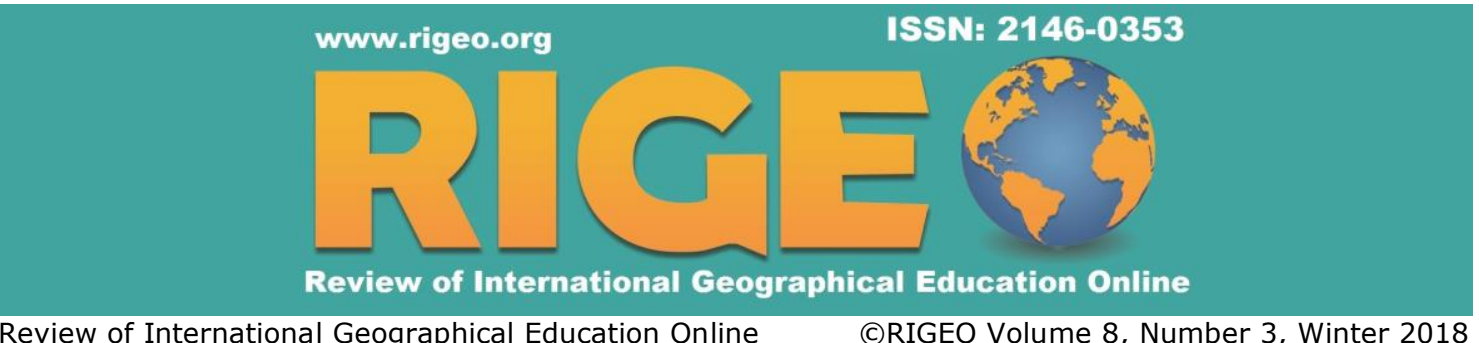

To cite this article: Aydın, F; Tülümen, M. (2018). Examining the Anxiety and Attitudes of Secondary School Students towards Geography Lessons in terms of Some Variables. Review of International Geographical Education Online (RIGEO), 8 (3), 473-499. Retrieved from http://www.rigeo.org/vol8no3/Number3winter/RIGEO-V8-N3-4.pdf

\title{
Examining the Anxiety and Attitudes of Secondary School Students towards Geography Lessons in terms of Some Variables*
}

\author{
Fatih AYDIN ${ }^{1}$ \\ Karabük University, Karabük, TURKEY \\ Murat TÜLÜMEN² \\ Ministry of National Education, Ankara, TURKEY
}

\begin{abstract}
The purpose of this study is to reveal the relation between anxiety and attitude scores of the secondary school students. In addition to this, in the present study, the anxiety and attitude scores of the students for Geography lesson were examined in terms of their achievement levels, gender, grade level and school type variables. The relational screening model was used in the present study and total of 2854 students attending to secondary schools in Karabük city center joined the research within the 20162017 academic year. In the present study, it was determined that there is a moderate-level, negative and significant relation between the anxiety and attitude scores of the secondary school students. In addition, it was also determined that the anxiety levels of the students about Geography lessons were low; however, their attitude levels were positive. In the present study, a significant difference was detected between the gender, achievement level, class level and type of school and Geography attitude averages of the students. It was also determined in the present study that as the success levels of the students increased, and the geography lesson anxiety scores decreased. In the present study, it was determined that there were no significant differences between the geography lesson anxiety scores and gender and grade levels of the students.
\end{abstract}

Keywords

Geography; Anxiety; Attitude; Geography Anxiety; Geography Attitude

\footnotetext{
*This work was supported by Research Fund of the Karabuk University. Project Number: KBU-BAP-17-YL-054 ${ }^{1}$ Corresponding author: Prof. Fatih Aydın; Department of Geography, Faculty of Letters, Karabuk University, Karabuk, Turkey. E-mail: fatihaydin [at] karabuk.edu.tr

2Ministiry of Natioal Education, Principal, Yahya Kemal Beyatlı Vocational and Technical Anatolian High School, Karabuk, Turkey. E-mail: murattulumen [at] hotmail.com
} 
Education is not only a specific concept but also a multicolored and multidimensional phenomenon that includes many elements such as philosophy, sociology, psychology and culture. Education with the most general and inclusive definition; it is the process of changing persistent behavioral behavior in individuals. Education is not a process aiming to make the individual know only the things s/he does not know (cognitive skills), make them do what they cannot do (psycho-motor skills). In addition to being equipped with knowledge and skills, education has philosophical, sociological and psychological focuses that are indispensable (Akar and Demirhan, 2017).

As of the process of perceiving the objects in the environment where the individual lives, the learning process starts to occur. The perception of natural environmental elements also constitutes the period in which the first geographical knowledge of individual is formed. In this situation, the requirement of having geography education in general education comes spontaneously to the agenda (Aksoy, 2004). Geography teaching is among the core lessons at all stages of education. With this teaching, it is aimed to educate a world citizen who has grasped the formation of geographic knowledge, has the ability to establish th e relationship between human-place, has the ability to question geographically, has a geographical environment that lives, respects the natural life and is sensitive to the problems of today's world. In general, the basic objectives of the Geography education are:

1. Examining human interactions with the nature and to ensure that human beings make use of the nature in the most efficient way. Countries have built the foundation of development plans on geographical basis. People would like to understand the natural environment. The reason of this is that societies have to plan their human and economic activities like agriculture, tourism, transportation, industry and residence according to the natural environment. Geography includes planning and using the space with a holistic approach. When considered in this context, geography is a place science (Koç and Aksoy, 2017, p.31).

2. Many investment decisions like the social and economic development of a country's administrative regions, the priority issues in investments, and determining the model for investments require deep systematic geographical information. For example, the investments which will be made for the purpose of improving agriculture in a region where water resources are limited and geological formation consists mainly of gypsum and limestone will not be profitable at a great deal (Doğanay, 2011).

3. Maps are one of the most important information and communication means coming from the past to our present time. Geography education is important to be able to take advantage of maps effectively. It is possible to use maps in almost all areas of military, economic and social life. It is possible to use maps in almost all areas of military, economic and social life. For example, he us es maps in site-specific studies such as the identification of the distribution areas of underground and aboveground sources and the identification of road routes (Koç and Bulut, 2014, p. 3). 
4. Geography provides a lot of knowledge that we can use in everyday life. People make decisions based on this geographical knowledge. For example, we use geographical factors for the purpose of selecting where we will live.

5. With geography, individuals learn how to analyze current political events from a real, objective and subjective viewpoint (with a holistic perspective). A geography literate individual questions the causes of political events and draws conclusions about the possible consequences of this political event and how a conjuncture will develop against these results. When the political, economic and similar problems among countries cannot be solved in a diplomatic and democratic way, military interventions become inevitable. Geographical knowledge is very important in military interventions. Geographical knowledge is questioned for preparing for a war (information is obtained about the roads, tunnels, bridges, straits, swamps, reeds, populations, landforms, climate, vegetation etc., i.e. all natural and human factors) in determining the time of attacks, determining attacks lines, in taking control of routes, etc. (Koç and Aksoy, 2017).

6. Geography is one of the most basic tools in establishing the love for one's homeland. Homeland is the geography itself. The source of the love for one's national is the cultural values of the nation like its language, history, literature, art and folklore (Doğanay, 1993). Not only does the Geography lessons introduce the natural, economic, historical and cultural characteristics of one's homeland, but it also teaches how to protect these beauties. In individuals who acquire geographic consciousness, the consciousness for homeland is also developed. With Geography, one learns the place of his/her country in the whole world, its boundaries, the area it covers, its landforms, population, underground and aboveground wealth. As one recognizes his/her homeland, $\mathrm{s} /$ he understands that his/her country is the most beautiful country in the world in terms of climate, landforms and natural wealth. In this way, his/her love for his/her country increases more (Kaya, 2013, p. 27).

7. Geography education is very important for educating responsible, sensitive individuals who perceive the environment correctly and who are interested in the environmental problems of the whole world starting from the environment where they live. Today, Geography education is taught under the name of "Environmental Education" in some countries and the basic goal is to leave a livable world for tomorrow's children. Geography lesson has an important place in the teaching of environmental probl ems, which are the result of human-nature interaction and which have an important place in today's world problems.

\section{Purpose of the Research}

One of the important factors affecting the success of students in the education process is anxiety and attitude. Anxiety includes one or more of the excitements such as sadness, distress, fear, sense of failure, helplessness and trial (Cüceloğlu, 1991). Attitude is the tendency to react positively or negatively to certain objects, situations, institutions, concepts or other people (Tezbaşaran, 1997). In other words, the attitude towards the geography course can be expressed as the positive or negative emotion 
against the individual's geography lesson. Excessive anxiety and negative attitude towards geography course is an important obstacle in the teaching of the course. The research revealed the problems of geography education in Turkey (Akınoğlu, 2005; Gokce, 2009; Koçman, 1999; Koçman and Sütgibi, 2004; Ozey, 1998; İbret, Aydın and Turgut, 2018; Sahin, 2003), herein lies the fundamental problem of what is geography, purpose and life they are united on what is not fully expressed. This situation causes students to develop negative attitudes about Geography course and also to increase their concerns about geography.

When the relevant literature was examined, it was seen that various studies were conducted to determine the attitudes of secondary school students towards Geography (Özkılıç, 2003; Çakmakl1, 2004; Tekinarslan, 2006; Zaman and Coşkun, 2007; Şengül, 2007; Alım, 2008; Tomal, 2010; Aydın, 2011; Aydın, Coşkun and Kaya, 2010; Göcen, 2011; Özdemir, 2012; Sumesh \& Abdul Gafoor, 2013; Onuoha \& Eze, 2013; Şahin, 2015; Kaba, 2016). In these studies, it was reported that the attitudes of students towards geography lessons were positive in general. Previous studies also reported that for the purpose of developing positive attitudes towards geography lessons, it was necessary to use student-centered teaching methods and techniques in classes, to ensure that students participated effectively to the activities in and outside the classroom, the classroom environment should be made suitable for geography lesson, out-of-classroom learning environments should be used, effective communication should be established in the classroom by the teacher, and the use of teaching materials that are specific for geography lessons.

There are studies showing the relationship between anxiety and attitude scores in different fields of science (social studies, science, math, etc.). (Akgün, Gönen and Aydın, 2007; Akın, 2014; Çelen, 2014; Çepni, 2015; Oğur, 2009; Yılmazer and Demir, 2014). The purpose of the present study is to determine the relation between the anxiety levels and attitude scores of secondary school students. We tried to fill this gap with the present study. We also consider that the findings of this study will help educators to understand the effects of the anxiety and attitudes of students towards the lesson. In addition, with the help of anxiety items, the geography anxiety levels of the students will be determined. These and similar other studies conducted on the current situation will help to identify the problems that come to the forefront in geography education process and will also help to show different solutions.

The main problem sentence of this study is "Is there a significant relation between the anxiety and attitudes of secondary school students towards the Geography lesson?" Following sub problems are bewlow according to main problems:

1. How are the anxiety levels of secondary school students in geography lessons in general; and do these levels differ according to various variables at a significant level?

2. How do the attitudes of secondary school students differ in Geography lessons at a significant level according to some variables? 
3. Is there a relation between the anxiety levels and attitudes of secondary school students for geography lessons?

\section{Methodology}

\section{Research Design}

This research is in the relational survey model because it is aimed to determine the relationship of the students ' concerns and attitudes towards geography courses to each other and to various variables (success, gender, class level, school type). Correlation analysis is performed to determine the relationship between two or more variables and to obtain clues about cause-and-effect (Büyüköztürk, Kılıç-Çakmak, Akgün, Karadeniz and Demirel, 2008).

\section{The Universe and Sample in Research}

The universe of this research consists of the students of Secondary Education in Karabük province and the sample of the year 2016-2017 consists of 8 different secondary education types in Karabük province. In the sampling process, it was cared that information was obtained from secondary education institution with different characteristics and number (Anatolian High School, Anatolian Teacher High School, Science High School, Imam-Hatip (Theology) (Theology) High School, Vocational High School for Girls, Commercial Vocational High School, Vocational Health High School, and Vocational Technical and Industrial High School).

The descriptive statistics of the secondary school students who participated in the present study are given in Table 1 and Table 2.

Table 1

Distributions of the Students Who Participated in the study according to Gender and Grade Level (The Frequency and Percentage)

\begin{tabular}{cccc}
\hline & Demographic Characteristics & Number of Students & Percentage (\%) \\
\hline \multirow{3}{*}{ Gender } & Boys & 1344 & 47.1 \\
\cline { 2 - 4 } & Girls & 1510 & 52.9 \\
\cline { 2 - 4 } & Total & 2854 & 100 \\
\hline \multirow{3}{*}{ Grade Level } & $9^{\text {th }}$ Grade & 368 & 12.9 \\
\cline { 2 - 4 } & $10^{\text {th }}$ Grade & 1220 & 42.7 \\
\cline { 2 - 4 } & $11^{\text {th }}$ Grade & 1056 & 37 \\
\cline { 2 - 4 } & $12^{\text {th }}$ Grade & 210 & 7.4 \\
\cline { 2 - 4 } & Total & 2854 & 100 \\
\cline { 2 - 4 } & Total & & \\
\cline { 2 - 4 } & & & \\
\hline
\end{tabular}

As shown in Table 1 , a total of $52.9 \%(f=1510)$ of the students who participated in the study were girls, and $47.1 \%(f=1344)$ were boys. A total of $12.9 \%(f=368)$ of the students were at $9^{\text {th }}$ Grade, $42.7 \%(f=1220)$ were at $10^{\text {th }}$ Grade, $37 \%(f=1056)$ were at $11^{\text {th }}$ Grade, and $7.4 \%(f=210)$ were at $12^{\text {th }}$ Grade. 
Aydın, F; Tülümen, M. (2018). Examining the anxiety and attitudes of secondary school students....

Table 2

Distributions of the Students who Participated in the Study according to School Type (The

Frequency and Percentage)

\begin{tabular}{|c|c|c|c|}
\hline School Type & Schools & $\begin{array}{l}\text { Number of } \\
\text { Students }\end{array}$ & $\begin{array}{l}\text { Percentage } \\
(\%)\end{array}$ \\
\hline \multirow{6}{*}{ Anatolian High School } & Demir Çelik Anatolian High School & 475 & \multirow{6}{*}{57.1} \\
\hline & 75. Y1l Karabük Anatolian High School & 337 & \\
\hline & $\begin{array}{l}\text { Vakıfbank Zübeyde Hanım Anatolian } \\
\text { High School }\end{array}$ & 269 & \\
\hline & $\begin{array}{l}\text { Kiymet and Mustafa Yazıcı Anatolian } \\
\text { High School }\end{array}$ & 188 & \\
\hline & Cumhuriyet Anatolian High School & 214 & \\
\hline & Fevzi Çakmak Anatolian High School & 146 & \\
\hline $\begin{array}{l}\text { Vocational High School } \\
\text { for Girls }\end{array}$ & $\begin{array}{l}\text { Yahya Kemal Beyatlı Vocational and } \\
\text { Technical Anatolian High School }\end{array}$ & 144 & 5 \\
\hline $\begin{array}{l}\text { Commerce Vocational } \\
\text { High School }\end{array}$ & $\begin{array}{l}\text { Necip Fazıl Kisakürek Vocational and } \\
\text { Technical Anatolian High School }\end{array}$ & 110 & 3.9 \\
\hline $\begin{array}{l}\text { Health Vocational High } \\
\text { School }\end{array}$ & $\begin{array}{l}\text { Prof. Dr. Süheyl Ünver Vocational and } \\
\text { Technical Anatolian High School }\end{array}$ & 176 & 6.2 \\
\hline $\begin{array}{l}\text { Technical and Industry } \\
\text { Vocational High School }\end{array}$ & $\begin{array}{l}\text { Karabük Vocational and Technical } \\
\text { Anatolian High School }\end{array}$ & 222 & 7.8 \\
\hline \multirow[t]{2}{*}{$\begin{array}{l}\text { Imam Hatip (Theology) } \\
\text { High School }\end{array}$} & $\begin{array}{l}\text { Karabük Anadolu Imam Hatip } \\
\text { (Theology) High School for Boys }\end{array}$ & 247 & \multirow[t]{2}{*}{11.9} \\
\hline & $\begin{array}{l}\text { Karabük Anadolu Imam Hatip } \\
\text { (Theology) High School for Girls }\end{array}$ & 92 & \\
\hline $\begin{array}{l}\text { Anadolu Teacher } \\
\text { Training High School }\end{array}$ & Alparslan Gazi Anatolian High School & 31 & 1.1 \\
\hline \multirow[t]{2}{*}{ Science High School } & $\begin{array}{l}\text { Karabük Mehmet Vergili Science High } \\
\text { School }\end{array}$ & 203 & 7.1 \\
\hline & Total & 2854 & 100 \\
\hline
\end{tabular}

As shown in Table 2, students from 8 different secondary school types participated in the study. Students from Anatolian High School $(f=1629)$, Vocational High School for Girls $(f=144)$, Commerce Vocational High School $(f=110)$, Health Vocational High School $(f=176)$, Technical and Industry Vocational High School $(f=222)$, Imam-Hatip (Theology) High School $(f=471)$, Anadolu Teacher Training High School $(f=31)$ and Science High School $(f=203)$ participated in the study.

\section{Data Collection Tool}

The "Geography Lesson Attitude Scale" and "Geography Lesson Anxiety Scale" were used in the study as the data collection tools. 
Geography lesson attitude scale. Geography Lesson Attitude Scale, which was developed by Aydin (2009), was used to determine the attitudes of the secondary school students towards Geography lessons. The Cronbach Alpha Reliability Coefficient of the attitude scale was found as .94. According to the results of the Factor Analysis of the attitude scale, the scale consisted of four factors. The correlations of the items in the factors with the item factor total score changed from 0.50 to 0.79 . The scale, which consisted of a total of 34 items, was prepared in the form of 5-Point Likert style; "Always" and "Never" (Aydın, 2009). A pilot implementation was carried out on 174 secondary school students to determine the reliability of the items in this attitude scale; and its Cronbach Alpha internal consistency coefficient was found to be .71.

Geography lesson anxiety scale. In order to determine the anxiety levels of the secondary school students in Geography lessons, the scale, which was developed by Kağıtçı and Kurbanoğlu (2013) for science lessons, and which was adapted to Geography lessons, and which was adapted to Geography lessons in line with the specialist viewpoints, was employed. The scale, which consisted of a total of 14 items, was prepared as "Always" and "Never" in a 5-Point Likert style. A pilot application was conducted on 174 secondary school students to determine the reliability of the items of the anxiety scale that was employed in the present study. The Cronbach Alpha Internal Consistency Coefficient of the scale was determined to be .81 .

\section{Collection and Analysis of the Data}

The data of the study were collected by applying the measurement scales to 2854 students who studies at 8 different secondary schools in Karabük in the second semester of 2016-2017 Academic Year. The implementation lasted for approximately 25 minutes. In the first examination, a total of 30 papers were accepted to be not valid; and the analyses were carried out over 2854 students. The SPSS 22 was employed to analyze the study data. The $\boldsymbol{t}$-test was employed in the analysis of the anxiety and attitude scores of the secondary school students for Geography lessons according to "gender" variable; and the One-Way Variance Analysis (ANOVA) was employed in the analysis of the data according to "grade", "achievement perception", and "school type". The "Tukey HSD" and the "LSD" were employed in determining the statistical differences between the two groups that appeared after the variance analysis. The Correlation Analysis was carried out in determining the relations between the anxiety and attitude levels of the secondary school students, who participated in the present study. The significance level of the scale in statistical analyses was found as 0.05.

\section{Findings}

\section{General Anxiety Status of the Secondary School Students in Geography Lesson}

The general anxiety levels of the secondary school students who participated in the study in Geography lessons are shown in Table 3. 
Table 3

The anxiety levels of the secondary school students in Geography lessons

\begin{tabular}{|c|c|c|}
\hline Statements & Sd & $\overline{\mathrm{X}}$ \\
\hline 1. I am nervous and bored before Geography lesson. & 1.22 & 1.89 \\
\hline 2. Even the idea of taking the Geography lesson makes me anxious. & 1.20 & 1.73 \\
\hline 3. Hearing words about Geography makes me anxious. & 1.16 & 1.72 \\
\hline 4. I feel uneasy in Geography lesson. & 1.26 & 1.85 \\
\hline $\begin{array}{l}\text { 5. I feel anxious about the teacher's observing me when performing the } \\
\text { activities in this lesson. }\end{array}$ & 1.28 & 1.93 \\
\hline $\begin{array}{l}\text { 6. I feel anxious when I am working with groups friends for Geography } \\
\text { lesson. }\end{array}$ & 1.06 & 1.56 \\
\hline 7. The subjects I do not understand in Geography lesson make me anxious. & 1.40 & 2.34 \\
\hline 8. I refrain from answering the questions even if I know the answer. & 1.23 & 1.85 \\
\hline 9. I feel anxious when I take the Geography textbook at my hand. & 1.15 & 1.65 \\
\hline $\begin{array}{l}\text { 10. Interpreting the graphics and tables in Geography lesson makes me } \\
\text { anxious. }\end{array}$ & 1.26 & 2.03 \\
\hline $\begin{array}{l}\text { 11. I feel anxious because of the possibility of the teacher's asking me } \\
\text { questions. }\end{array}$ & 1.36 & 2.17 \\
\hline $\begin{array}{l}\text { 12. The possibility of giving an incorrect answer to a question asked in } \\
\text { Geography lesson makes my anxious. }\end{array}$ & 1.38 & 2.30 \\
\hline $\begin{array}{l}\text { 13. The presence of students who are more successful than me makes me } \\
\text { anxious. }\end{array}$ & 1.30 & 1.89 \\
\hline $\begin{array}{l}\text { 14. I feel anxious that I cannot prepare the activities in given time period in } \\
\text { Geography lesson. }\end{array}$ & 1.37 & 2.19 \\
\hline
\end{tabular}

When Table 3 is examined it is seen that the items with the highest arithmetic averages in the answers given by the secondary school students about Geography lesson:

1. The subjects I do not understand make me anxious $(\bar{X}=2.34)$.

2. The possibility of giving an incorrect answer to a question in Geography lesson makes me anxious $(\bar{X}=2.30)$.

3. I feel anxious that I cannot prepare the activities in given time period in Geography lesson $(\bar{X}=2.19)$.

As a result, it is seen that the anxiety levels of the secondary school students for Geography lesson are at low level $(\overline{\mathrm{X}}=1.94)$.

\section{The Comparison of the Anxiety Scores of the Secondary School Students in} Geographic Lesson in terms of Achievement Levels in this Lesson

The results of the ANOVA Test which was conducted for the difference of anxiety scores of the secondary school students who participated in the study according to success level variable are given in Table 4. 
Table 4

The Results of the ANOVA Test according to Success Level Variable of the Secondary School Students in Geography Lesson

\begin{tabular}{|c|c|c|c|c|c|c|c|}
\hline & Category & $\mathbf{N}$ & $\mathbf{X}$ & $\mathbf{S}$ & $\mathbf{F}$ & $\mathbf{p}$ & Difference \\
\hline \multirow{5}{*}{$\begin{array}{l}\text { Success } \\
\text { Level }\end{array}$} & (1) $0-49.99$ (Fail) & 365 & 2.29 & .99 & 24.497 & $.000^{*}$ & \multirow{5}{*}{$\begin{array}{l}1-2 ; 1-3 \\
1-4 ; 1-5 \\
2-4 ; 2-5\end{array}$} \\
\hline & (2) 50.00-59.99 (Pass) & 650 & 2.02 & .89 & & & \\
\hline & (3) 60.00-69.99 (Moderate) & 603 & 1.90 & .82 & & & \\
\hline & (4) $70.00-84.99$ (Good) & 690 & 1.84 & .86 & & & \\
\hline & (5) $85.00-100$ (Very Good) & 546 & 1.76 & .81 & & & \\
\hline
\end{tabular}

When Table 4 is examined, it is seen that the anxiety scores of the secondary school students in Geography lesson differ at a significant level according to the success levels $\left[f_{(4,2849)}=24.50, p<.05\right]$. In other words, the secondary school students who have success at different levels have significant difference in terms of anxiety levels for Geography lesson.

\section{Comparison of the Anxiety Levels of Secondary School Students in Geography Lesson in terms of School Type}

The results of the ANOVA test showing the anxiety levels of the secondary school students who participated in the study according to the school type are given in Table 5.

Table 5

The Results of ANOVA Test Showing the Anxiety Levels of the Secondary School Students, who Participated in the Study, in Geography Lesson in terms of School Type Variable

\begin{tabular}{|c|c|c|c|c|c|c|}
\hline Category & $\mathbf{N}$ & $\mathbf{X}$ & $\mathbf{S}$ & $\mathbf{F}$ & p & Difference \\
\hline (1) Anatolian High School & 1629 & 2.04 & .92 & 15.010 & $.00^{*}$ & $1-2$ \\
\hline (2) Vocational High School for Girls & 144 & 1.73 & .67 & & & 1-3; \\
\hline (3) Commerce High School & 110 & 1.72 & .83 & & & 1-4; \\
\hline (4) Health High School & 176 & 1.59 & .67 & & & $1-6$ \\
\hline $\begin{array}{l}\text { (5) Technical ve Industry Vocational } \\
\text { High School }\end{array}$ & 222 & 1.97 & .89 & & & $\begin{array}{l}2-7 ; \\
3-7\end{array}$ \\
\hline (6) Imam Hatip (Theology) High School & 339 & 1.67 & .63 & & & $4-5$ \\
\hline $\begin{array}{l}\text { (7) Anadolu Teacher Training High } \\
\text { School }\end{array}$ & 31 & 2.35 & 1.10 & & & $\begin{array}{l}4-7 \\
5-6\end{array}$ \\
\hline (8) Science High School & 203 & 1.93 & .96 & & & \\
\hline
\end{tabular}

According to the scores given in Table 5, the anxiety levels of the secondary school students in Geography lesson show significant differences $\left[f_{(7,2846)}=15.010 ; p<0.05\right]$. When the average anxiety scores of the secondary school students are examined in terms of school types, it is seen that the highest average score is in Anatolian Teacher Training High School; and the lowest average score is in Health High School. In this respect, it is possible to claim that the students who have the highest anxiety scores about Geography lessons are the students of Anatolian Teacher Training High Schools; and the students who have the lowest anxiety scores are the students of Health High Schools. 
Aydın, F; Tülümen, M. (2018). Examining the anxiety and attitudes of secondary school students....

\section{Comparison of the Anxiety Levels of the Secondary School Students in Geography Lessons according to Grade Levels}

The results of the ANOVA Test, which was conducted for the difference of the anxiety levels of the secondary school students, who participated in the study according to grade level variable are given in Table 6.

Table 6

The results of the ANOVA Test anxiety levels of the secondary school students according to grade level variable

\begin{tabular}{cccccc}
\hline Category & $\mathbf{N}$ & $\mathbf{X}$ & $\mathbf{S}$ & $\mathbf{F}$ & $\mathbf{p}$ \\
\hline $9^{\text {th }}$ Grade & 368 & 1.97 & .81 & 1.874 & $.132^{* *}$ \\
\hline $10^{\text {th }}$ Grade & 1220 & 1.90 & .86 & & \\
\hline $11^{\text {th }}$ Grade & 1056 & 1.98 & .91 & & \\
\hline $12^{\text {th }}$ Grade & 210 & 1.92 & .93 & & $* *>.05$
\end{tabular}

When Table 6 is examined, it is seen that the anxiety levels of the secondary school students do not differ at a statistically significant level in Geography lesson according to the grade level $\left[f_{(4,2849)}=1.87, p>.05\right]$. In other words, the anxiety scores of the $9^{\text {th }}$, $10^{\text {th }}, 11^{\text {th }}$ and $12^{\text {th }}$ Grade students in Geography lesson show similarities.

\section{Comparison of the Anxiety Levels of the Secondary School Students in Geography Lesson according to Gender}

The $t$-test that was conducted for the difference of the anxiety levels of the secondary school students who participated in the study according to gender variable are given in Table 7.

Table 7

The Results of the t-test of the Anxiety Levels of the Secondary School Students in Geography Lesson according to Gender Variable

\begin{tabular}{lcccccc}
\hline & \multicolumn{2}{c}{ Male $(\boldsymbol{n}=\mathbf{1 3 4 4})$} & \multicolumn{2}{c}{ Female $(\boldsymbol{n}=\mathbf{1 5 1 0})$} & \multirow{2}{*}{$\boldsymbol{*}$} & \multirow{2}{*}{$\boldsymbol{p}$} \\
\cline { 2 - 5 } & $\overline{\mathrm{X}}$ & $\boldsymbol{S}$ & $\overline{\mathrm{X}}$ & $\boldsymbol{S}$ & & .64 \\
\hline Anxiety & 1.95 & .93 & 1.93 & .83 & & .64 \\
\hline
\end{tabular}

When Table 7 is examined it is seen that the anxiety levels of the secondary school students in Geography lesson do not differ at a statistically significant level according to the gender variable $\left[t{ }_{(2854)}=.64, p>.05\right]$. In other words, gender is not a defining element in the anxiety levels of the secondary school student in Geography lessons.

\section{The General Attitude Status of the Secondary School Students in Geography Lesson}

The general attitude status of the secondary school students who participated in the study in Geography lesson are given in Table 8. 
Table 8

The Attitude Status of the Secondary School Students in Geography lesson

\begin{tabular}{|c|c|c|}
\hline Statements & Sd & $\overline{\mathrm{X}}$ \\
\hline 1. Geography is one of the lessons I love. & 1.34 & 3.23 \\
\hline 2. I do not like Geography lesson at all. & 1.36 & 3.61 \\
\hline 3. The most unpleasant lesson among others is Geography. & 1.30 & 3.77 \\
\hline 4. I am not interested in Geography lesson. & 1.40 & 3.10 \\
\hline $\begin{array}{l}\text { 5. The lesson I study with great enthusiasm is Geography compared to other } \\
\text { lessons. }\end{array}$ & 1.29 & 2.50 \\
\hline 6. Geography lesson is necessary and important for every student. & 1.28 & 3.24 \\
\hline $\begin{array}{l}\text { 7. I do not understand Geography lesson subjects, for this reason, I do not } \\
\text { want to learn Geography. }\end{array}$ & 1.34 & 3.55 \\
\hline 8. I feel under pressure in Geography lessons. & 1.27 & 3.86 \\
\hline 9. No matter how much I study, I cannot succeed in Geography. & 1.34 & 3.55 \\
\hline 10. Geography lesson does not have anything to fear. & 1.34 & 3.40 \\
\hline 11. I am not interested in Geography lesson subjects. & 1.37 & 3.37 \\
\hline 12. The things I learn in Geography lesson are very useful in my daily life. & 1.28 & 3.16 \\
\hline 13. Aside from some basic knowledge, knowing Geography is unnecessary. & 1.35 & 3.35 \\
\hline 14. Geography does not have anything to add to my life. & 1.26 & 3.71 \\
\hline 15. I will be happy if the Geography lesson hours are reduced. & 1.50 & 3.26 \\
\hline 16. I refrain from Geography lesson examinations. & 1.45 & 3.31 \\
\hline 17. I take the Geography lesson because I have to. & 1.45 & 3.32 \\
\hline 18. I study Geography lesson because my teachers make me to do it. & 1.26 & 3.84 \\
\hline 19. Geography lesson helps us to recognize our country better. & 1.25 & 3.75 \\
\hline 20. Geography lesson subjects arouse curiosity in me. & 1.33 & 3.11 \\
\hline 21. Geography lesson requires thinking. & 1.27 & 3.26 \\
\hline 22. I would like to receive Geography lesson throughout my school life. & 1.36 & 2.69 \\
\hline $\begin{array}{l}\text { 23. The attitude, performance, use of various tools of the teacher -the teacher } \\
\text { competency in brief- are effective in having an enjoyable Geography lesson. }\end{array}$ & 1.33 & 3.74 \\
\hline 24. I enjoy discussing the things I learn at Geography lesson with my friends. & 1.31 & 2.84 \\
\hline 25. I think that the time I spend on Geography lesson is "wasted". & 1.34 & 3.69 \\
\hline $\begin{array}{l}\text { 26. I am happy because I acquire the ability of making interpretations about } \\
\text { the nature in Geography lesson. }\end{array}$ & 1.29 & 3.30 \\
\hline $\begin{array}{l}\text { 27. With the help of the Geography lesson, I follow the publishing closely on } \\
\text { the universal problems like "global warming, desertation and water problem". }\end{array}$ & 1.32 & 3.03 \\
\hline 28. Doing the homework of Geography makes me have fun. & 1.33 & 2.68 \\
\hline 29. I look forwards to Geography lesson hours & 1.30 & 2.50 \\
\hline 30. I feel anxious when I hear the name of the Geography lesson. & 1.33 & 3.68 \\
\hline 31. I want that Geography lesson becomes more enjoyable. & 1.30 & 3.70 \\
\hline 32. I would feel more peaceful I there were no Geography lessons. & 1.40 & 2.69 \\
\hline 33. I do not like the teaching of the Geography Teacher. & 1.45 & 3.56 \\
\hline 34. I am thinking of choosing a profession related to Geography in the future. & 1.25 & 2.07 \\
\hline
\end{tabular}


The items that have the highest arithmetic averages among the answers given by the secondary school students who participated in the study in Geography lesson are:

1. I feel under pressure in Geography lessons $(\bar{X}=3.86)$.

2. I study Geography because the teacher makes me to do it $(\bar{X}=3.84)$.

3. The most unpleasant lesson among the other lessons is Geography ( $\bar{x}=3.77$ ).

The answers of the secondary school students about the negative attitude items are similar to those that are about positive attitudes. For example, "Geography is a lesson I love" statement was agreed by the students at a rate of $27.9 \%(\mathrm{f}=797)$ as "I agree", $20.1 \%(\mathrm{f}=575)$ as "I totally agree". "I am not interested in Geography lesson" was responded as "I do not agree at all" at a rate of $28.2 \%(\mathrm{f}=806)$, and $20.3 \%(\mathrm{f}=578)$.

The items to which the secondary school students agreed ("I agree", and "I totally agree") at the highest level among the positive attitude statements are;

$\checkmark$ Geography lesson helps us to know our country better (68.5\%).

$\checkmark$ The attitude, performance, the use of tools of the teacher in Geography lesson the competency of the teacher in brief- are effective in having an enjoyable lesson (\%66).

$\checkmark$ I would like that Geography lessons is more enjoyable (64.7\%).

The statements to which the secondary school students did not agree at all ("I do not agree" and "I do not agree at all") among the general attitude statements are;

$\checkmark$ I study Geography lesson because the teacher makes me to do it (68.8\%).

$\checkmark \quad$ I feel under pressure in Geography lessons (68.6\%).

$\checkmark$ The most unpleasant lesson among the other lessons is Geography $(64.1 \%)$.

The statements to which the secondary school students responded as "I am indecisive" in the attitude scale that was applied in the study are;

$\checkmark$ The things I learn at Geography lesson are very useful in my daily life (28.2\%).

$\checkmark$ I would like to receive Geography lesson throughout my school life (26.1\%).

$\checkmark$ I enjoy discussing the things I learn at Geography lesson with my friends $(25.7 \%)$.

\section{Comparison of Attitude Levels of Secondary School Students in Geography Lesson according to Success Levels in Lesson}

The results of the ANOVA Test, which was conducted for the difference of the attitude levels of the secondary school students in Geography lesson according to the success levels in lessons are given in Table 9. 
Table 9

The Results of the ANOVA Test Conducted according to the Success Levels in Lessons to Determine the Attitude Levels of the secondary school students in Geography Lessons

\begin{tabular}{|c|c|c|c|c|c|c|c|}
\hline Dimensions & Success Level & $\mathbf{N}$ & $\mathbf{X}$ & $\mathbf{S}$ & $\mathbf{F}$ & $\mathbf{p}$ & Difference \\
\hline \multirow{5}{*}{ Liking } & (1) 0-49.99 (Fail) & 365 & 3.07 & .70 & 39.98 & $.00 *$ & $1-2 ; 1-3$ \\
\hline & (2) 50.00-59.99 (Pass) & 650 & 3.30 & .69 & & & $1-5 ; 2-3$ \\
\hline & (3)60.00-69.99 (Moderate) & 603 & 3.43 & .68 & & & $2-4 ; 2-5$ \\
\hline & (4) $70.00-84.99$ (Good) & 690 & 3.54 & .68 & & & $3-5$ \\
\hline & (5) 85.00-100 (Very Good) & 546 & 3.57 & .68 & & & \\
\hline \multirow{5}{*}{ Interest } & (1) $0-49.99$ (Fail) & 365 & 2.49 & .81 & 13.89 & $.00 *$ & $1-2$ \\
\hline & (2) 50.00-59.99 (Pass) & 650 & 2.74 & .85 & & & 1-3; \\
\hline & (3)60.00-69.99 (Moderate) & 603 & 2.85 & .82 & & & $1-4$ \\
\hline & (4) $70.00-84.99$ (Good) & 690 & 2.88 & .88 & & & 1-5; \\
\hline & (5) $85.00-100$ (Very Good) & 546 & 2.77 & .96 & & & $2-4$ \\
\hline \multirow{5}{*}{ Importance } & (1) $0-49.99$ (Fail) & 365 & 3.08 & .97 & 20.97 & $.00 *$ & $1-2$ \\
\hline & (2) 50.00-59.99 (Pass) & 650 & 3.40 & .90 & & & $1-3$ \\
\hline & (3)60.00-69.99 (Moderate) & 603 & 3.50 & .85 & & & 1-4; \\
\hline & (4) 70.00-84.99 (Good) & 690 & 3.61 & .87 & & & 1-5; \\
\hline & (5) 85.00-100 (Very Good) & 546 & 3.47 & .96 & & & $2-4$ \\
\hline \multirow[t]{5}{*}{ Expectation } & (1) $0-49.99$ (Fail) & 365 & 3.28 & .81 & 14.24 & $.00^{*}$ & $1-2$ \\
\hline & (2) 50.00-59.99 (Pass) & 650 & 3.49 & .76 & & & 1-3; \\
\hline & (3)60.00-69.99 (Moderate) & 603 & 3.58 & .80 & & & $1-4$ \\
\hline & (4) $70.00-84.99$ (Good) & 690 & 3.65 & .81 & & & $1-5$ \\
\hline & (5) $85.00-100$ (Very Good) & 546 & 3.59 & .83 & & & $2-4$ \\
\hline
\end{tabular}

When Table 9 is examined it is seen that the attitude levels of the secondary school students in Geography lesson according to the success levels in lessons variable differed at a statistically significant level in liking the lesson $\left[f_{(4,2849)}=39.98, p<.05\right]$, interest $\left.\left[f_{(4,2849}\right)=13.89, p<.05\right]$, importance $\left[f_{(4,2849)}=20.97, p<.05\right]$ and expectation $\left[f_{(4,}\right.$ $2849)=14.24, p<.05]$ dimensions. In other words, success in the lessons is an important variable in the attitudes of the secondary school students towards Geography lesson.

\section{Comparison of the Attitude Levels of the Secondary School Students in Geography Lesson according to the School Type Variable}

The results of the ANOVA Test, which was conducted to determine the attitude levels of the secondary school students who participated in the study according to the school type variable are given in Table 10. 
Aydın, F; Tülümen, M. (2018). Examining the anxiety and attitudes of secondary school students....

Table 10

The Results of the ANOVA Test of the Secondary School Students according to the School Type Variable in Geography Lesson

\begin{tabular}{|c|c|c|c|c|c|c|c|}
\hline Dimensions & School Type & $\mathbf{N}$ & $\mathbf{X}$ & $\mathbf{S}$ & $\mathbf{F}$ & $\mathbf{p}$ & Difference \\
\hline \multirow{9}{*}{ Liking } & $\begin{array}{l}\text { (1) Anatolian High } \\
\text { School }\end{array}$ & 1629 & 2.04 & .92 & \multirow[t]{9}{*}{5.010} & \multirow[t]{9}{*}{$.000 *$} & \multirow{9}{*}{$\begin{array}{l}1-2 ; \\
1-3 ; \\
1-4 ; \\
1-6 ; \\
2-7 \\
3-7 \\
4-5 ; \\
4-7 ; \\
5-6\end{array}$} \\
\hline & $\begin{array}{l}\text { (2) Vocational High } \\
\text { Schol for Girls }\end{array}$ & 144 & 1.73 & .67 & & & \\
\hline & (3) Commerce High & 110 & 1.72 & .83 & & & \\
\hline & School & & & & & & \\
\hline & $\begin{array}{l}\text { (4) Health High } \\
\text { School }\end{array}$ & 176 & 1.59 & .67 & & & \\
\hline & $\begin{array}{l}\text { (5) Technical ve } \\
\text { Industry Vocational } \\
\text { High School }\end{array}$ & 222 & 1.97 & .89 & & & \\
\hline & $\begin{array}{l}\text { (6) Imam Hatip } \\
\text { (Theology) High } \\
\text { School }\end{array}$ & 339 & 1.67 & .63 & & & \\
\hline & $\begin{array}{l}\text { (7) Anadolu Teacher } \\
\text { Training High School }\end{array}$ & 31 & 2.35 & 1.10 & & & \\
\hline & $\begin{array}{l}\text { (8) Science High } \\
\text { School }\end{array}$ & 203 & 1.93 & .96 & & & \\
\hline \multirow{10}{*}{ Interest } & $\begin{array}{l}\text { (1) Anatolian High } \\
\text { School }\end{array}$ & 1629 & 2.80 & .90 & \multirow{9}{*}{19.729} & \multirow{9}{*}{$.000 *$} & \multirow{9}{*}{$\begin{array}{l}1-2 ; \\
1-8 \\
2-3 \\
2-4 \\
2-5 \\
2-6 \\
3-8 \\
6-8\end{array}$} \\
\hline & $\begin{array}{l}\text { (2) Vocational High } \\
\text { School for Girls }\end{array}$ & 144 & 3.20 & .71 & & & \\
\hline & (3) Commerce High & 110 & 2.72 & .85 & & & \\
\hline & School & & & & & & \\
\hline & $\begin{array}{l}\text { (4) Health High } \\
\text { School }\end{array}$ & 176 & 2.60 & .85 & & & \\
\hline & $\begin{array}{l}\text { (5) Technical ve } \\
\text { Industry Vocational } \\
\text { High School }\end{array}$ & 222 & 2.78 & .81 & & & \\
\hline & $\begin{array}{l}\text { (6) Imam Hatip } \\
\text { (Theology) High } \\
\text { School }\end{array}$ & 339 & 2.88 & .81 & & & \\
\hline & $\begin{array}{l}\text { (7) Anadolu Teacher } \\
\text { Training High School }\end{array}$ & 31 & 2.66 & .74 & & & \\
\hline & $\begin{array}{l}\text { (8) Science High } \\
\text { School }\end{array}$ & 203 & 2.20 & .76 & & & \\
\hline & $\begin{array}{l}\text { (1) Anatolian High } \\
\text { School }\end{array}$ & 1629 & 3.45 & .93 & \multirow{4}{*}{17.278} & \multirow{4}{*}{$.000 *$} & $\begin{array}{l}1-2 \\
1-6\end{array}$ \\
\hline \multirow{3}{*}{ Importance } & $\begin{array}{l}\text { (2) Vocational High } \\
\text { School for Girls }\end{array}$ & 144 & 3.82 & .73 & & & $\begin{array}{l}1-8 \\
2-3\end{array}$ \\
\hline & $\begin{array}{l}\text { (3) Commerce High } \\
\text { School }\end{array}$ & 110 & 3.38 & .95 & & & $\begin{array}{l}2-5 \\
2-6\end{array}$ \\
\hline & (4) Health High & 176 & 3.33 & .79 & & & $3-8$ \\
\hline
\end{tabular}




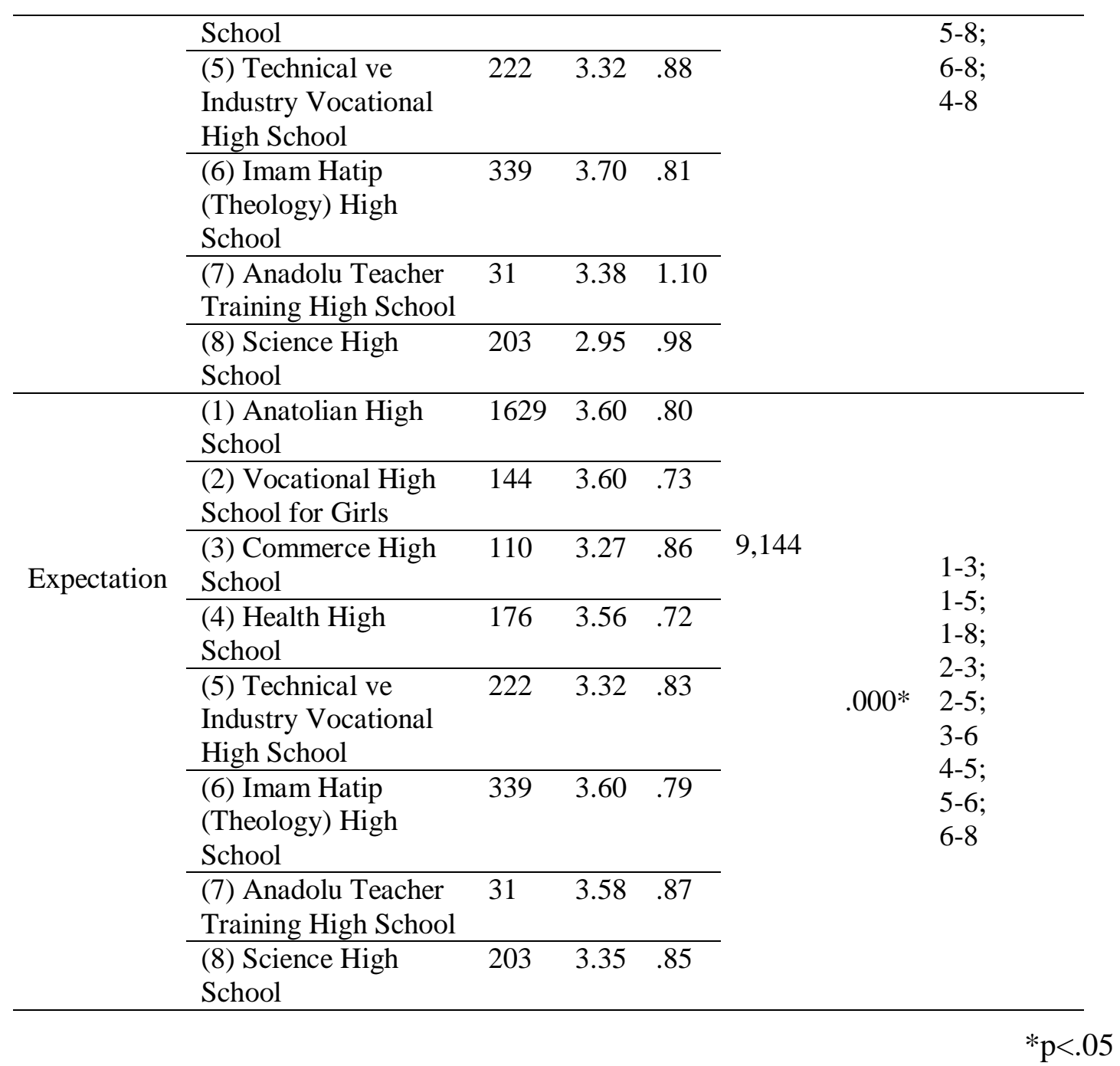

According to the values in Table 10, it is seen that the attitude scores of the secondary school students in Geography lessons differed at a statistically significant level in liking, interest, importance, and expectation dimensions.

\section{Comparison of the Attitude Scores of the Secondary School Students according to Grade Levels in Geography Lessons}

The results of the ANOVA test, which was conducted for the difference between the attitude scores of the secondary school students, who participated in the study, according to grade level variables are given in Tale 11. 
Aydın, F; Tülümen, M. (2018). Examining the anxiety and attitudes of secondary school students....

Table 11

The Results of the ANOVA Conducted according to the Grade Level Variable of the Attitude Levels of the Secondary School Students in Geography Lesson

\begin{tabular}{|c|c|c|c|c|c|c|c|}
\hline Dimensions & Grade levels & $\mathbf{N}$ & $\mathbf{X}$ & $\mathbf{S}$ & $\mathbf{F}$ & $\mathbf{p}$ & Difference \\
\hline \multirow{4}{*}{ Liking } & (1) $9^{\text {th }}$ Grade & 368 & 3.45 & 74 & \multirow[t]{4}{*}{3.95} & \multirow[t]{4}{*}{$.00 *$} & 1-3; \\
\hline & (2) $10^{\text {th }}$ Grade & 1220 & 3.43 & 69 & & & 2-3; \\
\hline & (3) $11^{\text {th }}$ Grade & 1056 & 3.35 & 71 & & & $3-4$ \\
\hline & (4) $12^{\text {th }}$ Grade & 210 & 3.48 & .64 & & & \\
\hline \multirow{4}{*}{ Interest } & (1) $9^{\text {th }}$ Grade & 368 & 2.88 & .91 & \multirow[t]{4}{*}{6.68} & \multirow[t]{4}{*}{$.00 *$} & $1-2$ \\
\hline & (2) $10^{\text {th }}$ Grade & 1220 & 2.75 & .85 & & & 1-3; \\
\hline & (3) $11^{\text {th }}$ Grade & 1056 & 2.73 & .89 & & & $2-4$ \\
\hline & (4) $12^{\text {th }}$ Grade & 210 & 2.97 & .87 & & & $3-4$ \\
\hline \multirow{4}{*}{ Impotance } & (1) $9^{\text {th }}$ Grade & 368 & 3.48 & .91 & \multirow[t]{4}{*}{1.66} & \multirow[t]{4}{*}{$.17 * *$} & \\
\hline & (2) $10^{\text {th }}$ Grade & 1220 & 3.44 & .91 & & & \\
\hline & (3) $11^{\text {th }}$ Grade & 1056 & 3.41 & .94 & & & \\
\hline & (4) $12^{\text {th }}$ Grade & 210 & 3.55 & .87 & & & \\
\hline \multirow{4}{*}{ Expection } & (1) $9^{\text {th }}$ Grade & 368 & 3.62 & .80 & \multirow[t]{4}{*}{2.11} & \multirow{4}{*}{$.09 * *$} & \\
\hline & (2) $10^{\text {th }}$ Grade & 1220 & 3.53 & .79 & & & \\
\hline & (3) $11^{\text {th }}$ Grade & 1056 & 3.51 & .83 & & & \\
\hline & (4) $12^{\text {th }}$ Grade & 210 & 3.59 & .84 & & & \\
\hline
\end{tabular}

When Table 11 is examined it is seen that the attitudes of the Secondary School Students in Geography lessons differed at a statistically significant level according to the grade level variable in liking $[f(4,2849)=3.95, p<.05]$ and interest $[f(4,2849)=$ $6.68, p<.05]$ dimensions; however, it is also seen that attitude levels did not differ at a statistically significant level in importance $[f(4,2849)=1.66, p>.05]$ and expectation $[f(4,2849)=2.11, p>.05]$ dimensions. In other words, while the grade level is a significant variable in the liking and interest dimensions in the attitudes of the Secondary School Students in Geography lesson, it is not a significant variable in terms of the importance and expectation dimensions.

\section{Comparison of the Attitude Levels of the Secondary School Students in Geography Lesson according to Gender}

The results of the $t$-test, which was conducted for the difference of the attitude levels of the Secondary School Students, who participated in the study, in Geography lesson according to the gender variable are given in Table 12. 
Table 12

The t-test Results of the Attitude Levels of the Secondary School Students according to the Gender Variable in Geography Lessons

\begin{tabular}{|c|c|c|c|c|c|c|}
\hline \multirow[t]{2}{*}{ Dimensions } & \multicolumn{2}{|c|}{$\begin{array}{c}\text { Boys } \\
(n=1344)\end{array}$} & \multicolumn{2}{|c|}{$\begin{array}{c}\text { Girls } \\
(n=1510)\end{array}$} & \multirow[t]{2}{*}{$\mathbf{t}$} & \multirow[t]{2}{*}{$\mathbf{p}$} \\
\hline & $\overline{\bar{X}}$ & $S$ & $\overline{\bar{X}}$ & $S$ & & \\
\hline Liking & 3.41 & .71 & 3.41 & .70 & .05 & $.96^{* *}$ \\
\hline Interest & 2.81 & .88 & 2.74 & .87 & 1.89 & $.06^{* *}$ \\
\hline Impotance & 3.39 & .94 & 3.49 & .90 & -2.70 & $.00^{*}$ \\
\hline Expection & 3.48 & .86 & 3.59 & .76 & -3.59 & $.00^{*}$ \\
\hline
\end{tabular}

When Table 12 is examined, it is seen that the attitude levels of the Secondary School Students in Geography lesson did not differ at a statistically significant level according to gender variable in liking $[t(2854)=.05, p>.05]$ and interest $[t(2854)=$ $1.89, p>.05$ ] dimensions; however, it is also seen that there are statistically significant differences in importance $[t(2854)=-2.70, p<.05]$ and expectation $[t(2854)=-3.59, p$ $<.05]$ dimensions. In other words, while liking and interest dimensions are not important variables in the attitudes of the Secondary School Students in Geography lessons; it is an important variable in the importance and expectation dimensions. In addition, when the average values are examined, it is seen that the significant difference in importance and expectation dimensions is in favor if the girl students. In other words, girls have higher attitude levels than boys in importance and expectation dimensions.

\section{The Relations between the Attitudes and Anxiety of the Secondary School Students in Geography Lesson}

The results of the correlation analysis that was made to determine the relations between the attitudes and anxiety of the Secondary School Students in Geography lesson are given in Table 13.

Table 13

The Relation between the Attitude and Anxiety of the Secondary School Students in Geography lessons

\begin{tabular}{lccccc}
\hline & $\mathbf{1}$ & $\mathbf{2}$ & $\mathbf{3}$ & $\mathbf{4}$ & $\mathbf{5}$ \\
\hline 1. Anxiety & - & $-.64^{* *}$ & $-.34^{* *}$ & $-.40^{* *}$ & $-.31^{* *}$ \\
2. Liking & & - & $.60^{* *}$ & $.62^{* *}$ & $.47^{* *}$ \\
3. Interest & & & - & $.63^{* *}$ & $.51^{* *}$ \\
4. Impotance & & & & - & $.54^{* *}$ \\
5. Expection & & & & & - \\
\hline
\end{tabular}

When Table 13 is examined it is seen that there are significant relations between the anxiety and attitudes of the Secondary School Students in Geography lessons. In this context, there is a negative and statistically significant relation in the anxiety attitude scale with liking $(r=-.64, p<.05)$, interest $(r=-.34, p<.05)$, importance $(r=-.40, p$ $<.05)$ and expectation $(r=-.31, p<.05)$ dimensions. In other words, the anxiety and 
Aydın, F; Tülümen, M. (2018). Examining the anxiety and attitudes of secondary school students....

attitudes of the secondary school students in Geography lessons move in reverse directions.

\section{Result and Discussion}

In the present study, it was determined that there is a negative and significant relation between the anxiety and attitude scores of the secondary school students in Geography lessons. In other words, as the anxiety levels of the students who participated in the study increased, their attitudes towards the lesson become more negative. When the relevant literature is examined it is seen that similar results were reported in different science branches (Akman et al., 2007; Çepni, 2015; Doğan and Çoban, 2009; Fraser \& Fisher, 1982; Kağıtçı, 2014; Karadeniz, 2014; Kurbanoğlu, 2014; Peker and Şentürk, 2012; Sağır, 2012; Yaman, 2014). For example, in the study that was conducted by Çepni (2015), it was concluded that there is a negative and significant relation between the anxiety and attitude scores of the secondary school students in social sciences lessons. In the study that was conducted by Karadeniz (2014), it was reported that there is a moderate significant relation between he mathematics anxiety and mathematical attitudes of the secondary school students who studies at rural areas; and as the mathematical anxiety increased, so the mathematical attitudes decreased at a similar rate. In addition, it is also considered that the low levels in education and socio-economic status in families cause that the anxiety increase in students, and in this way, these students develop a negative attitude towards mathematics. Kağıtçı (2014) conducted a study and reported that there is a moderate, negative and significant relation between the anxiety and attitude scores of the students in science lesson.

In this study, it was determined that the anxiety scores of the secondary school students differed at a statistically significant level in Geography lessons according to the success level variable. It was observed that the anxiety scores of the students who considered that they were successful in Geography lessons were lower than those who considered that they were unsuccessful. These results supported the results of other studies that were conducted on different fields (Çepni, 2015; Kağıtçı, 2014; Çelen, 2014; Akgün, Gönen and Aydın, 2007). For example, Akgün, Gönen and Aydın (2007) found significant relations between the success levels and anxiety scores of Science and Mathematics Teacher candidates and determined that there is a significant relation between the success levels and anxiety scores of the students, which supported the relevant studies.

In the present study, it was found that there are no differences at significant levels between the Geography anxiety scores of the secondary school students and the gender variable. In other words, gender is not a defining element in the anxiety levels of secondary school students in Geography lessons. In similar studies that were conducted in different disciplines (Çepni, 2015; Dede and Dursun, 2008; Kağıtçı, 2014; Yenilmez and Özbey, 2006), it was determined that there were no differences at significant levels between the anxiety scores and the gender variable. 
According to another result that was obtained in this study, the anxiety levels of secondary school students in Geography lessons did not differ at a statistically significant level according to the class level variable. In this respect, it was observed that the grade level variable did not have any significant effects on the anxiety scores in Geography lessons. In similar studies (Çepni, 2015; Kağıtçı, 2014; Yenilmez and Midilli, 2006) concluded that the grade level was not a defining element on anxiety.

In this study, it was concluded that the attitudes of the secondary school students towards Geography lesson were positive. This finding supports the findings of previous studies examining the attitudes of secondary school students towards Geography lessons. For example, Aydın (2011) and Özdemir (2012) conducted a study in Karabük and reported that students had positive attitudes towards Geography lessons. In the study conducted by Alim (2008), it was reported that the attitudes of the secondary school students towards Geography lessons were at a moderate level. Tekinarslan (2006) conducted a study and reported that $3^{\text {rd }}$ Graders in secondary education had positive considerations about the benefits of Geography lessons. In the study that was conducted by Şahin (2015), it was reported that the interest of students in Geography lessons were positive at a significant level. Zaman and Coşkun (2007) conducted a study with a sampling of 512 students in Erzurum and reported that secondary school students had positive attitudes towards Geography lessons in general; however, there were also some differences in these attitudes. In the study that was conducted by Kaba (2016) on $9^{\text {th }}$ Graders in Kahramanmaraş city center, it was reported that students had positive attitudes towards Geography lessons in general. The study that was conducted by Gerber (2001) in Australia reported that the attitudes of students towards Geography lessons were positive. In addition, the studies that examined the attitudes of undergraduate students towards geography (Demirkaya and Arıbaş, 2004; Dikmenli and Aslan, 2009; Gökçe, 2010; Kadığlu, 2008; Ulusoy and Gülüm, 2009) also reported similar findings. The results of the relevant literature show that students have positive attitudes towards Geography lessons. In general, Geography lesson is a discipline that is loved and has a place in society. Aydin (2011) conducted a study with students and determined the reasons of student's love for Geography lessons as the lessons' being enjoyable, topics being interesting and related to daily life and teacher's attitudes. Based on this, it may be claimed that the way to change some of the negative attitudes of students towards Geography lessons depends on the presence of Geography teachers who love their professions and make their work in a righteous manner. Because Geography, whose contents exist in every stage of daily life, becomes interesting in the classroom environment depending on the teacher's following in-class applications, knowledge, communication skills, technological pedagogical content knowledge and innovations and carrying them to the classroom environment.

In the present study, a significant relation was detected between the attitudes of the students towards Geography lessons and their success levels. As it is already known, the negative attitudes of the students towards a lesson shows that it avoids the students from participating in the teaching and learning processes; and decreases their achievement levels in lessons. Increasing the level of interest of the students in geography lessons, 
creating active learning media and developing positive attitudes will affect their success in this lesson in a direct manner. Studies have shown that having positive attitudes for Geography by students increases their success (Aksoy, 2004; Coşkun, 2004; Demirkaya, 2003; Önal, 2008; Paul, 2007; Sack \& Petersen, 1998; Sevilmiş, 2006; Verma \& Despande, 2016).

It was determined that the attitudes of secondary school students who participated in the study varied according to the school types variable. In other words, the school type is an important variable in terms of the geography attitudes of the students. Although Geography lesson is taught with a single curriculum in all types of secondary education school types in our country, the interests and attitudes of students towards Geography lessons vary. There may be many reasons for this difference. Geography and some other similar lessons are considered within the scope of culture lessons in Vocational High Schools, which might reduce the importance of the lesson. Again, in Anatolian Teacher Training High Schools and Science High Schools, the focal points of the students are on math-based lessons and the low score of this lesson in the university entrance exams may decrease the interest in geography. Previous studies (Çakmakl1, 2004; Göcen, 2011; Kaba, 2016; Sevilmiş, 2006; Zaman and Coşkun, 2007) show that school type affect the attitude towards the Geography lesson. For example, Çakmaklı (2004) conducted a study and found that the interest of Vocational High School students in Geography was low, and it was higher in general high schools. Aydın, Coşkun and Kaya (2010) conducted a study and determined that the most important elements that affected the attitudes of Commerce Vocational High School students towards Geography lesson were the attitudes and performances of the teachers in lessons, the Geography lessons being enjoyable and teacher's teaching style.

In this study, although the attitudes of the secondary school students towards Geography lesson did not show significant differences according to the gender variable in the "liking" and "interest" dimensions, it is an important variable in the "importance" and "expectation" dimensions. In the "importance" and "expectation" dimensions, it was determined that girl students had higher attitude levels than males. In a similar study, Kaba (2016) reported that the attitudes of students towards Geography lessons differed according to the gender variable. In a study conducted by Göcen (2011) on $12^{\text {th }}$ Graders, it was determined that the attitudes of the girl students towards Geography lessons were more positive than those of the males. Göcen also stated that the students had more positive attitudes towards Geography lessons; which might be explained by girl students' being more interested in the teacher than males. Şengül (2007) conducted a study in K.K.T.C. and detected differences between male and female students in high schools in general sum, which were work habits, deficiencies in teaching, teachers, friends, curricula, extracurricular activities, school facilities, personal characteristics, family pressure, intelligence and social cohesion sub-dimensions. Aydın, Coşkun and Kaya (2010), Alım (2008), Cin (2007), Sevilmiş (2006), Demirkaya and Arıbaş (2004), Dikmenli and Aslan (2009), Lannes, Velloso \& Meis (2002), Özdemir (2012), Zaman and Coşkun (2007) conducted studies and reported that gender was not a defining factor on the attitudes of students towards Geography. 
In this study, although the grade level was an important variable in the attitudes of secondary school students towards Geography lessons in the "liking" and "interest" dimensions, it was not an important variable in the "importance" and "expectation" dimensions in terms of the attitude scores. As it is already known, as the grade level increases, especially in Anatolian High Schools, students determine their fields according to their targets, and take Geography lessons in this respect. In non-math groups both the number and the lessons hours increase. In the senior graders, on the other hand, the attitudes towards the lessons might change because of the anxiety for university entrance exams. Şengül (2007), who reported similar results, determined that the attitudes towards Geography lesson and the attitudes showed a significant difference in favor of the $11^{\text {th }}$ Graders in the sub-dimensions of "school facilities" and "judgment for the future". In another study, Aydın, Coşkun and Kaya (2010) reported that the attitudes of the students of the Commerce Vocational High School towards Geography lessons showed significant differences between $9^{\text {th }}$ Grade and $10^{\text {th }}$ Grade.

One of the important findings of the present study is that most of the students stated that they were "Indecisive" about the statement "What I learn in Geography lessons are very useful in my daily life", which indicates that there is a concerning situation in this respect. As it is already known, the use of the information obtained in a discipline in daily life is one of the most important indicators of the importance of that specific discipline. Meanwhile, it is also an indication showing the extent to which the information is learned. Today, geographic information is employed more intensively in daily life.

For example, the environmental problems occurring in any part of the world may be felt in many places at different scales. Previous studies (Aydın, 2011; Kenger, 2010; Tomal, 2009) show that adequate information is not given to students about the purpose, importance and applicability of Geography lessons in daily life. In this respect, teachers have great responsibilities. Teachers must include subjects related to close environment more and organize research trips on the subjects that are covered in the lesson. When the related literature is examined, the attitude and performance of Geography teacher in the lesson is the major cause affecting the attitudes of the students towards Geography lessons in a negative way. Despite the change in the curriculum, Geography teaching in our country is performed mostly with teacher-centered methods, techniques and strategies. When the fact that the student-centered education approach is at the forefront is considered, it is necessary that teachers must make Geography lessons into an environment where students can apply the knowledge they learn and become more active in Geography lessons. In addition to the use of student-centered teaching methods and techniques, the classroom media should be organized by considering the scientific technological opportunities of the modern age for Geography lessons to become more comprehensible and enjoyable. When the subjects of Geography, its interdisciplinary structure, its purpose, methods and the tools used by it are considered, it is seen that it makes more use of computer technologies compared to many other disciplines. In recent years, especially the use of Geographic Information Systems (GIS), Google Earth, animations, interactive boards, GPS, Remote Sensing Technologies in teaching 
Geography has caused that the lessons have become more permanent, efficient and interesting (Kerski, 2003; Shin, 2006; Batty, 2010; Çepni, 2013; Artvinli 2009, 2010; Doğru and Aydın, 2018; Meydan and Oner, 2014; Kızılçaoğlu, 2010).

As a result, it was determined that there is a moderate, negative and significant relation between the anxiety and attitude scores of the secondary school students. The anxiety levels of secondary school students in Geography lessons is low; however, the attitude levels are above the moderate level. A significant difference was detected between the anxiety and attitude scores of the students and their success levels. As the success levels of the students increased, the anxiety scores in Geography lessons decreased, and Geography lesson attitude scores increased. It was determined that there were no significant differences between the geography lesson anxiety scores of the students and their gender. It was also determined that there was a significant difference between Geography lesson attitude scores and gender and the attitudes of the female students towards Geography lessons were more positive compared to those of male students. It was determined that there were no significant differences between the geography class anxiety scores and grade levels of the students. It was also observed that there was a significant difference between Geography lesson attitude scores and grade levels.

\section{Suggestions}

Based on the findings obtained in the study, the following recommendations may be made for practitioners and researchers:

$\checkmark$ When the related sources were examined, it was observed that there were no studies on the anxiety in Geography lessons in our country. Firstly, the number of similar studies must be increased.

$\checkmark$ For the purpose of determining and reducing the factors that cause the formation of anxiety for Geography in students, qualitative studies may be conducted.

$\checkmark$ In the formation and development of anxiety and negative attitudes towards Geography lesson, factors like exam anxiety, teachers' practices, friends, environment, homework, field knowledge, lack of self-confidence have effects at various levels. There is no doubt that Geography teachers have a significant role in eliminating these elements and realizing a healthy Geography teaching. Teachers should develop new strategies to reduce the anxiety of the students in Geography lessons and organize activities that will convert negative attitudes into positive ones. For the purpose of achieving the main target of the Geography lesson, first of all, the teachers should make necessary explanations on the necessity and importance of Geography lesson. The attention of the students must be attracted to the Geography lessons.

$\checkmark$ Some of the students who participated in the present study mentioned that Geography was not enjoyable. For the purpose of increasing the interest in Geography lessons, teachers can allocate more time for student-centered teaching methods, and organize trips to the close surroundings, which may affect the interests and attitudes of the students in Geography in a positive manner. 
$\checkmark$ The attitudes of the secondary school students towards the Geography lesson differed according to the type of school. Although the same curriculum is applied in all secondary and formal secondary schools, this difference is noteworthy. It should be considered as a detailed research topic whether the difference is caused by students' personal characteristics or other variables.

In this study, a lack of knowledge about what geography works in daily life has been identified. Our teachers should follow current publications about the Geography course and prepare timeframes for current topics in their schools.

\section{References}

Akar, C. \& Demirhan, G. (2017). Temel kavramlar. A. Sezer (Edt.), Coğrafya ögrretim teknolojileri ve materyal tasarımı içinde (s. 1-15). Ankara: Pegem Akademi.

Akgün, A., Gönen, S. \& Aydın, M. (2007). İlköğretim fen ve matematik öğretmenliği öğrencilerinin kaygı düzeylerinin bazı değişkenlere göre incelenmesi. Sosyal Bilimler Dergisi, 6(20), 283-299.

Akın, M. Y. (2014). Birleştirilmişs sınıflı ilkokul öğrencilerinin sosyal bilgiler dersine yönelik tutumları. Yayımlanmamış yüksek lisans tezi, Bülent Ecevit Üniversitesi, Zonguldak.

Akınoğlu, O. (2005). Coğrafya eğitiminin etkililiği ve sorunları. Marmara Coğrafya Dergisi, $12,77-96$.

Akman, B., İzgi, Ü., Bağçe, H. \& Akı1ll, H. İ. (2007). İlköğretim öğrencilerinin Fen'e karş1 tutumlarının sinav kaygı düzeylerine etkisi. Eğitim ve Bilim Dergisi, 32(146), 3-11.

Aksoy, B. (2004). Coğrafya ögrretiminde probleme dayalı ögrenme yaklaşımı. Yayınlanmamış Doktora Tezi. Gazi Üniversitesi, Eğitim Bilimleri Enstitüsü, Ankara.

Alım, M. (2008). Lise öğrencilerinin coğrafya dersine yönelik tutumları. Doğu Coğrafya Dergisi, 19, 25-33.

Artvinli, E. (2009). Coğrafya öğretmenlerinin Coğrafi Bilgi Sistemleri (CBS)'ne ilişkin yaklaşımları. Balıkesir Üniversitesi Sosyal Bilimler Enstitüsü Dergisi, 12(22), 40-57.

Artvinli, E. (2010). The Contribution of geographic information systems (GIS) to geography education and secondary school students' attitudes related to GIS. Educational Sciences: Theory and Practice, 10(3), 1277-1292

Aydın, F. (2009). İşbirlikli ögrenme yönteminin 10. sinıf coğrafya dersinde başarıya, tutuma ve motivasyona etkileri. Yayımlanmamış Doktora Tezi. Gazi Üniversitesi Eğitim Bilimleri Enstitüsü, Ankara.

Aydın, F. (2011). Secondary school students' opinions about geography course: A qualitative study. Archives of Applied Science Research, 3(1), 297-305.

Aydın, F., Coşkun, M. \& Kaya, H. (2010). Ticaret meslek lisesi öğrencilerinin coğrafya dersine yönelik tutumlarının değerlendirilmesi. Çankırı Karatekin Üniversitesi Sosyal Bilimler Enstitüsü Dergisi, 1, 183-203.

Batty, M. (2010). Using geographical information systems (Key Methods in Geography, Eds: Nicholas Clifford, Shaun French, Gill Valentine), SAGE Publications Ltd, USA. 
Aydın, F; Tülümen, M. (2018). Examining the anxiety and attitudes of secondary school students....

Büyüköztürk, Ş., Kılıç-Çakmak, E., Akgün, Ö. E., Karadeniz, Ş. \& Demirel, F. (2008). Bilimsel araştırma yöntemleri. Ankara: Pegem Publishing.

Cin, M. (2007). Sınıf öğretmeni adaylarının coğrafya dersine olan ilgi düzeyleri ve cinsiyet farklı1ıkları. Doğu Coğrafya Dergisi, 18, 39-48.

Cüceloğlu, D. (1991). İnsan ve davranışı (2.Bask1). İstanbul: Remzi.

Coşkun, M. (2004). Coğrafya eğitiminde proje tabanlı öğrenme yaklaşımı. Yayımlanmamış Doktora Tezi. Gazi Üniversitesi Eğitim Bilimleri Enstitüsü, Ankara.

Çakmaklı, M. (2004). Güngören ilçesinde farklı programların uygulandı̆̆ ortaöğretim kurumlarındaki öğrencilerin coğrafya dersine karşı tutumları ve bunların karşılaştırılması. Yayımlanmamış Yüksek Lisans Tezi. Marmara Üniversitesi Eğitim Bilimleri Enstitüsü, İstanbul.

Çelen, A. (2014). 6. ve 7. Sınıf öğrencilerinin sosyal bilgiler dersine karşı tutumlarının incelenmesi (Malatya örneği). Yayımlanmamış Yüksek Lisans Tezi. İnönü Üniversitesi, Eğitim Bilimleri Enstitüsü, Malatya.

Çepni, O. (2013). The Use of geographic information systems (GIS) in geography teaching. World Applied Sciences Journal, 25(12), 1684-1689.

Çepni, O. (2015). Ortaokul öğrencilerinin sosyal bilgiler dersine yönelik kaygı ve tutumlarının çeşitli değişkenler açısından incelenmesi. Zeitschrift für die Welt der Türken-Journal of World of Turks, 7(2), 299-313.

Dede, Y. \& Dursun, Ş. (2008). İlköğretim II. kademe öğrencilerinin matematik kayg1 düzeylerinin incelenmesi. Uludağ Üniversitesi Eğitim Fakültesi Dergisi, 21(2), 295-312.

Demirkaya, H. \& Arıbaş, K. (2004). Sosyal bilgiler öğretmenliği üçüncü sınıf öğrencilerinin coğrafya dersine yönelik tutumlarının değerlendirilmesi. Selçuk Üniversitesi, Sosyal Bilimler Enstitüsü Dergisi, 12, 179-187.

Demirkaya, H. (2003). Coğrafya öğretiminde 4MAT öğretim sisteminin lise coğrafya derslerindeki başarı ve tutumlar üzerine etkisi. Yayımlanmamış Doktora Tezi. Gazi Üniversitesi Eğitim Bilimleri Enstitüsü, Ankara.

Dikmenli, Y. \& Aslan, C. A. (2009). Sınıf öğretmenliği birinci ve dördüncü sınıf öğrencilerinin coğrafya dersine yönelik tutumlarının karşılaştırılması. Ahi Evran Üniversitesi Eğitim Fakültesi Dergisi, 10(2), 29-36.

Doğan, T. \& Çoban, A. E. (2009). Eğitim fakültesi öğrencilerinin mesleğine yönelik tutumları ile kaygı düzeyleri arasındaki ilişkinin incelenmesi. Eğitim ve Bilim Dergisi, 34(153), 157-168.

Doğanay, H. (2011). Anlamı, tanımı, konusu ve felsefesi bakımından coğrafya ilmi hakkında bazı düşünceler. Doğu Coğrafya Dergisi, 25,1-44.

Doğru, E. \& Aydın, F. (2018). Coğrafya öğretmenlerinin teknolojik pedagojik alan bilgisi (TPAB) hakkındaki düşünceleri ve bunu kullanma durumları. Eğitim Kuram ve Uygulama Araştırmaları Dergisi (EKUAD), 4(2), 88-100.

Fraser, B. J. \& Fisher, D. L. (1982). Effects of anxiety on science-related attitudes. International Journal of Science Education, 4(4), 441-450. 
Gerber, R.V. (2001). Attitudes to Geography in Australia, Australian Geographer, 32(2), 221239.

Göcen, C. (2011). 12. Sinıf öğrencilerinin coğrafya dersine yönelik tutumları. Yayımlanmamış Yüksek Lisans Tezi. Gazi Üniversitesi Eğitim Bilimleri Enstitüsü, Ankara.

Gökçe, N. (2010). Sosyal bilgiler öğretmen adaylarının Coğrafya dersine yönelik tutumları. NWSA (e-Journal of New World Sciences Academy), 5(4), 2071- 2083.

İbret, Ü., Aydın, F. \& Turgut, T. (2018). Coğrafya eğitiminin birey yetiştirmedeki rolü. International Journal of Geography and Geography Education, 38, 1-19.

Kaba, R. (2016). 9. Sinıf öğrencilerinin coğrafya dersine karşı tutumları (Kahramanmaraş Örneği). Yayımlanmamış Yüksek Lisans Tezi. Atatürk Üniversitesi, Eğitim Bilimleri Enstitüsü, Erzurum.

Kadıŏ̆lu, Y. (2008). Sosyal bilgiler öğretmenliği birinci ve dördüncü öğrencilerinin coğrafya derslerindeki ilgi düzeylerinin karşılaştırılması. Marmara Coğrafya Dergisi, 17, 185-195.

Kağıtçı, B. (2014). Fen dersine yönelik kaygı ölçeği geliştirilmesi ve ortaokul ögrrencilerinin fen dersi kaygl ile tutum puanlarının çeşitli değişkenlere göre incelenmesi. Yayımlanmamış yüksek lisans tezi. Sakarya Üniversitesi, Eğitim Bilimleri Enstitüsü, Sakarya.

Karadeniz, E. (2014). Kırsal kesimdeki ortaokul öğrencilerinin matematiğe ilişkin kaygıları ile matematik tutumları arasındaki ilişsk. Yayımlanmamış Yüksek Lisans Tezi. Eskişehir Osmangazi Üniversitesi Eğitim Bilimleri Enstitüsü, Eskişehir.

Kaya, H. (2013). Neden coğrafya? Neden coğrafya eğitimi? Yayımlanmamış Yüksek Lisans Tezi. Gazi Üniversitesi Eğitim Bilimleri Enstitüsü, Ankara.

Kenger, G. (2010). 9. Sinıf öğrencilerinin coğrafya dersinde öğrendikleri coğrafya kavramları günlük yaşamla ilişkilendirme düzeyinin belirlenmesi. Yayınlanmamış Yüksek Lisans Tezi. Marmara Üniversitesi Sosyal Bilimler Enstitüsü, İstanbul.

Kerski, J.J. (2003). The implementation and effectiveness of geographic information systems technology and methods in secondary education. Journal of Geography, 102(3), 128-137.

Kızılçaoğlu, A. (2010). Coğrafya Eğitiminde Google-Earth. İstanbul: Ezgi Kitabevi.

Koç, H. \& Bulut, İ. (2014). Gestalt kuramının öğrencilerin harita okuma ve yorumlama beceri düzeyleri üzerine etkisini belirlemeye yönelik bir inceleme, Marmara Coğrafya Dergisi, $30,1-19$.

Koç, H. \& Aksoy, B. (2017). Coğrafya öğretimi. A. Sezer (Edt.), Coğrafya öğretim teknolojileri ve materyal tasarımı içinde (s. 31-53). Ankara: Pegem Akademi.

Koçman, A. (1999). Cumhuriyet döneminde yüksek öğretim kurumlarında Coğrafya öğretimi ve sorunları. Ege Coğrafya Dergisi, 10, 1-14.

Koçman, A. \& Sütgibi, S. (2004). Geographical education and training at Turkish universities. International Research in Geographical and Environmental Education, 13(1), 97-102.

Kurbanoğlu, N. İ. (2014). Investigation of the relationships between high school students' chemistry laboratory anxiety and chemistry attitudes in terms of gender and types of school. Education and Science, 39(171), 199-210. 
Aydın, F; Tülümen, M. (2018). Examining the anxiety and attitudes of secondary school students....

Lannes, D. Rumjanek, V. M. Velloso, A. \& de Meis, L. (2002). Brazilian schools: Comparing students' interests with what is being taught. Educational Research, 44(2), 157-179.

Meydan, A. \& Öner, S. (2014). Coğrafi bilgi sistemleri ile öğretimin öğrencilerin coğrafya dersine yönelik tutumlarına etkisi. Turkish Studies, 9(11), 407-417.

Oğur, M. (2009). Altıncı ve yedinci sınıf ögrencilerinin sosyal bilgiler dersine yönelik tutumlarının incelenmesi. Yayımlanmamış yüksek lisans tezi. Pamukkale Üniversitesi, Denizli.

Önal, H. (2008). Coğrafya ögrretiminde aktif öğrenme uygulamaları. Yayımlanmamış Doktora Tezi, Gazi Üniversitesi Eğitim Bilimleri Enstitüsü, Ankara.

Öner, S. \& Aydın, F. (2014). The effects of geography information systems supported training on the academic success in geography course. Türkiye Sosyal Araştırmalar Dergisi, 18(3), 179-196.

Onuoha, J.C. \& Eze, E. (2013). Students' Attitude towards the study of geography in nsukka local government area, Enugu State. African Review of Arts Social Sciences \& Education, $3(1), 141-157$.

Özdemir, Ü. (2012). High school students' attitudes towards geography courses (Karabuk Sample-Turkey). World Applied Sciences Journal, 17(3), 340-346.

Özey, R. (1998). Türkiye üniversitelerinde coğrafya eğitimi ve öğretimi. İstanbul: ÖZeğitim Yayınları

Paul, W. (2007). Students' perceptions of geography: Decision making at age 14. Geography, 92(1), 62-73.

Peker, M. \& Şentürk, B. (2012). İlköğretim 5. sınıf öğrencilerinin matematik kaygılarının bazı değişkenler açısından incelenmesi. Dumlupınar Üniversitesi Sosyal Bilimler Dergisi, 34, 21-32.

Sack, D. \& Petersen, J. F. (1998). Children's attitudes toward geography: A texas case study. Journal of Geography, 97(3), 123-131.

Sağır, Ş. U. (2012). The primary school students' attitude and anxiety towards science. Journal of Baltic Science Education, 11(2), 127-140.

Sevilmiş (Kara), F. D. (2006). Lise birinci sınıf öğrencilerinin coğrafya dersine yönelik akademik benlik ve tutumları ile başarıları arasındaki ilişki (İzmir/Konak Ölçesi Örneği). Yayımlanmamıș Yüksek Lisans Tezi. Dokuz Eylül Üniversitesi Eğitim Bilimleri Enstitüsü. İzmir.

Shin, K. E. (2006). Using geographic information system (GIS) to improve fourth graders' geographic content knowledge and map skills. Journal of Geography, 105(3), 109-120.

Sumesh, P.M. \& Abdul Gafoor, P.K. (2013). Attitude of government and private school students towards geography education in calicut district of Kerala - A comparative study. Journal of Education and Human Development, 2(2), 58-63.

Şahin, C. (2003). Türkiye'de coğrafya öğretimi (sorunlar-çözüm önerileri), Ankara.: Gündüz Eğitim Yayınc1lık. 
Şahin, V. (2015). Otelcilik ve turizm meslek ortaöğretimsi öğrencilerinin coğrafya dersine olan ilgi ve algıları: Tekirdağ Örneği. Turkish Studies, 10(3), 817-832.

Şengül, N. (2007). K.K.T.C. 'deki liselerde coğrafya ĕ̆itiminde ögrencilerin coğrafya dersine olan ilgi ve tutumları. Yayımlanmamış Yüksek Lisans Tezi. Gazi Üniversitesi Eğitim Bilimleri Enstitüsü, Ankara.

Tekinarslan, H. (2006). Lise öğrencilerinin coğrafya dersine karşı tutumlarının değerlendirilmesi. Yayımlanmamış Yüksek Lisans Tezi. Gazi Üniversitesi Eğitim Bilimleri Enstitüsü, Ankara.

Tezbaşaran, A. (1997). Likert tipi ölçek geliştirme klavuzu. (2.baskı). Ankara: Türk Psikologlar Derneği yayınları.

Tomal, N. (2009). Coğrafya derslerinde edinilen bilgilerin günlük hayatta kullanılma durumları. Kastamonu Eğitim Dergisi, 17(1), 229-240.

Ulusoy, K. \& Gülüm, K. (2009). Sosyal bilgiler öğretmenliği öğrencilerinin tarih ve coğrafya derslerine yönelik tutumları (Adıyaman örneği). Dumlupınar Üniversitesi Sosyal Bilimler Dergisi, 25, 149-160.

Verma, M. \& Deshpande, S. (2016). Perception of students about Geography in FNU: A case study. Asia Pacific Institute of Advanced Research (APIAR), 2(1), 100-111.

Yaman, H. (2014). Ortaokul öğrencilerinin genel kaygı düzeyleri, yazma kaygıları ve türkçe dersine yönelik tutumları arasındaki ilişki. Kuram ve Uygulamada Ĕgitim Bilimleri, 14(3), 1111-1122.

Yenilmez, K. \& Midilli, P. (2006). İlköğretim öğrencileri ve velilerinin matematik kayg1 düzeyleri. Eskişehir Osmangazi Üniversitesi Sosyal Bilimler Dergisi, 7(2), 97-112.

Yenilmez, K. \& Özbey, N. (2006). Özel okul ve devlet okulu öğrencilerinin matematik kayg1 düzeyleri üzerine bir araştırma. Uludağ Üniversitesi Eğitim Fakültesi Dergisi, 19(2), 431448.

Y1lmazer, A. \& Demir, S. B. (2014). Ortaokul öğrencilerinin sosyal bilgiler dersine ve sosyal bilgiler öğretmenine karşı tutumları ile akademik başarıları arasındaki ilişkinin incelenmesi. Turkish Studies, 9(2), 1705-1718.

Zaman, S. \& Coşkun, O. (2007). Orta öğretim öğrencilerinin coğrafya derslerine karşı tutumları üzerine bir araştırma (Erzurum örneği). Doğu Coğrafya Dergisi, 17, 17-31.

\section{Biographical statements}

Fatih AYDIN is a professor at the department of Geography at Karabuk University. His main focus areas are geography teaching in high schools, environmental education, cooperative learning, GIS in schools in geographical education.

Murat TÜLÜMEN is a Principal at the Yahya Kemal Beyatlı Vocational and Technical Anatolian High School in Karabuk. 